\title{
Reframing the Purpose of Business Education: Crowding-in a Culture of Moral Self-Awareness
}

\author{
Julian Friedland \\ MSU Denver College of Business \\ Tanusree Jain \\ Trinity Business School \\ [Accepted version, Journal of Management Inquiry, Online first, 07/18/20.]
}

"For at least another hundred years we must pretend to ourselves and to everyone that fair is foul and foul is fair; for foul is useful and fair is not. Avarice and usury and precaution must be our gods for a little longer still. For only they can lead us out of the tunnel of economic necessity into daylight."

- John Maynard Keynes

Keynes wrote that passage in 1930. So if he was right, we should finally be close to reaching the promised land he so fondly foretold - that moment when economic growth has raised the general standard of living to a point at which the problems of economic necessity to secure food, shelter, and leisure for the many have been practically removed. For then "it will remain reasonable to be economically purposive for others after it is has ceased to be reasonable for oneself" (Keynes, 1963). Keynes foresaw a golden era of shared humanity where virtue and the good life at last became of central cultural importance. With any luck, we may well be on the brink of getting there considering that business executives and thought leaders are now striving to fashion ethical frameworks by which to define the purpose and conduct of responsible business (Mackey \& Sisodia, 2014; Freeman, 2017; Freeman, Wicks \& Parmar, 2004). Equally, ethics and corporate 
social responsibility are taken increasingly seriously by academics and business schools alike (Christensen et al., 2007; Burchell et al., 2015; Doherty et al., 2015; Matten \& Moon, 2004). More than $90 \%$ of CEOs recognize the importance of sustainability for corporate profits and success. In addition, learning about CSR is a priority for about $88 \%$ of business school students, with up to $67 \%$ of them wanting to incorporate environmental sustainability into their career choices. This demand for sustainability both from corporates as well as students has resulted in an increase in mandatory business and society courses in business schools from 34\% in 2001 to 79\% in 2011 (Hoffman, 2018). In this manner, workplace postmaterialism (Giacalone \& Jurkiewicz, 2004), spirituality (Fry, 2003), and new virtue-based alternatives to financial hedonism (Edelson, 2017) point to the kind of progress Keynes intimated.

In the business world, the notion that the purpose of the business is to make profits for its owners under the shareholder primacy paradigm has been severely criticized and appears to be undergoing somewhat of a transition (Freeman \& Ginena, 2015). For example, Jack Welch, the former GE chief, who was once widely regarded as the father of the shareholder value movement was later quoted as saying that, "On the face of it, shareholder value is the dumbest idea in the world." (Guerrera, 2009). Perhaps most surprising is how some of the world's largest businesses and institutional investors, such as Unilever and Blackrock, are altering their business strategies by pro-actively including a social purpose (Fink, 2018). In terms of business school education, a growing interest in CSR and sustainability in MBA programs has been reported in the Times (UK) (Finn, 2008). Similarly, Ethical Corporation suggested that business schools emphasizing CSR as a core element are likely to be at a competitive advantage (Balch, 2007). Not surprisingly, a widespread commitment toward CSR education was found in leading business schools, both in North America and Europe (Christensen et al., 2007; Moon \& Orlitzky, 2011). 
In addition, an increasing number of business schools are now signatories of the UN's Principles of Responsible Management Education (PRME) that calls on business schools to integrate ethics, CSR and sustainability into their core activities (Burchell et al., 2015). PRME is increasingly viewed by scholars as an opportunity 'not only to rethink what is being taught in business schools, but also to question the pillars upon which management education was built' (Rasche \& Escudero, 2010, p. 246). In this vein, even prestigious business school accreditors such as EQUIS, AACSB and AMBA emphasize integrating ethics, responsibility and sustainability components in business school education.

Despite these developments, there is an emerging parallel debate on the redundancy of university education in general, and business schools in particular (Economist, 2016). For example, there is now a cottage industry of celebrity entrepreneurs encouraging the youth to opt out of college altogether (Byrne, 2010). The legendary investor Peter Thiel offers a $\$ 100,000$ fellowship to students to do just that (Greathouse, 2012) while others characterize college in general as a colossal waste of time and money (Caplan, 2018). Leading Fortune 500 companies have started skipping degree requirements for certain jobs (AthensCEO, 2018). With top schools such as Harvard, Stanford, and MIT now providing free massive open online courses (MOOCs), these changes, together with increasing numbers of competitors offering consulting and training courses, continue to pose a credible market threat to more costly and time-consuming college programs (Pfeffer \& Fong, 2002). Although to date, these trends have mostly affected nonbusiness programs, we argue that the market for MBAs is not immune to these changes. While enrollments at many traditional non-profit colleges and business schools remained relatively strong through 2017 (NSCRC, 2017), they have begun to drop off significantly over last two years, as more students are choosing reputable lower-tuition options, a pattern which is likely to 
intensify as the fertility slump of the Great Recession is felt (Conley, 2019). Indeed, the top 10 U.S. MBA programs have experienced significant declines in applicants with many in the double digits (Byrne, 2019). Such trends send an underlying message that college in the U.S., and perhaps the rest of the world, has become a bloated market bubble that is likely to burst once the wider population recognizes that myriad college programs are plausibly not worth the expense.

This market pressure for quick success on both students as well as business schools as institutions coupled with the rather simplified translation of time spent in pursuing a higher education into purely economic terms, results in the latter adopting a single-minded focus on justifying the student's return on investment. To deal with this crisis, universities attempt to promote themselves through high-profile movers and shakers who happen to be among their graduates—or may not even have graduated at all—Mark Zuckerberg and Bill Gates each received honorary degrees from their common alma mater long after they had dropped out. To stay relevant in this market, there is an increasing tendency to promote business school education as a shortcut to higher earnings. Indeed, financial success remains by far the most common metric that business schools continue to rely upon to help them stand out from the crowd (Feloni $\&$ Baer, 2014). Fueling this trend are influential rankings such as the Financial Times placing the most importance on expected future compensation and value for money (Ortmans, 2018). The latest Businessweek global ranking only includes 5 schools outside the U.S. in the top 50 as a result of expected future compensation being the number 1 factor of survey respondents (Businessweek, 2018). Consequently, such metrics may have become more important to recruiters than academic quality (Byrne, 2011). Collectively, this phenomenon equates individual and business success with financial success, proliferating a distorted view of what success means both in terms of business and profession. 
This mindset has been reinforced through well over a generation of economic incentives, which have created a cultural environment in which civic virtues have atrophied from disuse (Bowles, 2016). Unfortunately, neoclassical economic thinking has long held that personal preferences and incentives are separable - that is the former are merely additive and thus inert where incentives are concerned. This is because the homo-economic paradigm of human nature assumes that agents are only ever motivated by self-interest alone. Therefore, their personal preferences including ethical values have little or no effect on actual behavior. However, we now know that this once bedrock assumption is in fact false, for it has been repeatedly shown in countless studies that moral and other non-economic motives are often crowded out by explicitly financial incentives (Sandel, 2012). Indeed, an example of this crowding out effect is abundantly evident here as the very purpose of a college education has gradually shifted over a single generation from being construed as a collectively valuable social good and avenue for personal edification to becoming a mere means of securing a lucrative occupation (Natale \& Doran, 2012).

In such a markedly instrumentalist climate, it is easy for business schools to crowd out genuine commitment to social purpose in their graduates. Yet at the same time, the demand for it is evident and growing faster than ever given widespread student interest in ethics and social responsibility (Scott, 2015; NUS, 2019). There are differing perspectives on how business schools as institutions can embrace morality. One view is that institutional morality can be deduced from the individual morality of its key office bearers and as such an account of institutional morality involves unpacking the level of individual morality. At the same time, an alternative view suggests that institutional morality can be functionally deduced from the purpose of the institution and its likely effects (Hardin, 1988). Per this view, the rules and norms 
guiding the actions of individual office bearers are "determined by the functional relationship of their actions to the general purpose of the institutions" (Hardin, 1996: 127). In this essay, we adopt the latter view of institutional morality by integrating the institutional purpose debate. We argue that business schools now need to take the bull by the horns and reframe their conception of business purpose beyond mere financial success (Giacalone \& Thompson, 2006; Giacalone \& Promislo, 2013), failing which they are likely to suffer significant reputational loss if they are seen as dragging their feet against this broader social movement (Taylor, 2020). To achieve this aim, we offer a motivating strategy for crowding in a culture of professional ethics based on the concept of moral self-awareness, an evolving aspirational mindset informed by reflection on moral identity, namely what one's actions say about oneself given their positive or negative impacts on others and society (Friedland \& Cole, 2019). We begin by describing the current existential crisis in business purpose and introduce the concept of moral self-awareness as a motivational corrective. We then explain how crowding in a culture of moral self-awareness in business schools may require (1) reframing the purpose of business, (2) reframing the meaning of professional success, and (3) reframing the ethos of business education itself.

\section{A Crisis of Purpose}

The current existential crisis that business schools find themselves in is akin to the one medical and law schools in the U.S. endured a century ago before fashioning overarching standards of professional conduct and developing clearly articulated social missions via respected professional associations (Pfeffer \& Fong, 2004; Khurana, 2007). Though law and medicine gradually evolved to embrace compulsory professional ethics oaths reifying their respective social missions, business schools and their accreditors have yet to follow suit (Friedland, 2012). While standalone courses on ethics and corporate responsibility are gradually being introduced 
across business school curricula, they continue to take a back seat in business school promotion (Navarro, 2008). This is because personal wealth remains the imprimatur of business success par excellence.

Whereas, given the increasing price tag of U.S. college programs as compared to the cost of college education in the rest of the developed world, a heightened focus on the students' return on investment is understandable particularly in the US context (Rothman, 2016), there is no evidence to indicate that lower relative cost has made European business schools on the whole any more focused on ethics and social responsibility (Parliament UK, 2018). This should not be surprising as the creeping marketization of nearly every aspect of life, including higher education, has become a global cultural and behavioral problem for which it is often difficult to find clear corrective solutions (Bowles, 2016). Financial incentives have become ubiquitous, gradually crowding out other concerns such as the civic and prosocial (Atiq, 2014). For instance, a formidable stream of management literature over the last 40 years has focused on the business case for CSR or sustainability by emphasizing on its instrumental benefits (Bhattacharya \& Sen, 2004; McWilliams et al., 2006; Orlitzky et al., 2003; Tang et al., 2012), justifying prosocial activities merely on economic grounds (Gond et al, 2009) without adequately discussing pressing normative questions on the conditions under which and the approaches through which firms should or should not engage in CSR - irrespective and independent of its financial implications (Margolis et al., 2009; Jamali et al., 2018). Such an instrumental motive behind prosocial behaviors results in crowding out of the ethical reasons of being prosocial on one hand, while at the same time diminishing the ethical value of unprofitable prosocial behaviors (Gond et al., 2009). 
In many instances, such an amoral stance results in applauding organizations that may be morally corrupt yet prosocially visible. Indeed, several high-profile business leaders now find themselves caught up in reputational storms due in large part to lacking a systematic prosocial policy (Jain, 2017). Ethics scandals from Volkswagen and Wells Fargo to Uber, Ryanair and Facebook have jolted executive suites into realizing that stakeholders increasingly expect the businesses to go beyond feel-good philanthropy and social responsibility integration into business strategy, towards questioning the very essence of their business purpose (Bansal, 2019). For example, the Business Roundtable, an influential group of 200 CEOs, have upgraded their definition of corporate purpose by placing an equal emphasis on corporate responsibilities towards stakeholders (such as customers, employees, suppliers, and the environment) at par with shareholder responsibilities (MacLellan, 2019). Larry Fink, CEO of Blackrock, the world's largest investment firm, publicly announced in his 2018 letter to CEOs, that Blackrock now expects corporations to publicly articulate a strategic framework for long-term value creation reviewed by the board of directors (Fink, 2018):

"Companies must ask themselves: What role do we play in the community? How are we managing our impact on the environment? Are we working to create a diverse workforce? Are we adapting to technological change? Are we providing the retraining and opportunities that our employees and our business will need to adjust to an increasingly automated world? Are we using behavioral finance and other tools to prepare workers for retirement, so that they invest in a way that will help them achieve their goals?"

To back these claims, the company joined the Climate Action 100+, a group of the world's largest investors that pressure companies to act on climate change. It has also created a $\$ 50$ billion platform of dedicated sustainable investment solutions that align capital with certain 
behaviors, activities or outcomes via ESG (Environment, Social \& Governance), thematic, and impact approaches (Holger \& Sardon, 2020). This includes $\$ 40$ billion in clean energy investments and $\$ 500$ billion in investment solutions that eliminate exposures to certain sectors or activities through screened solutions.

Still, there remains much skepticism of leaders' intentions to act responsibly towards their stakeholders and society (Gratton, 2013) in a fashion that goes beyond appropriate public posturing (Jain, 2018). That is, there can be loose coupling between the image that companies project to stakeholders and society through their CSR and social impact programs and the real purpose behind a firm's existence (Jain, 2017). For example, Facebook CEO Mark Zuckerberg, seems to be at crossroads regarding what his company stands for. On one hand, there is the shareholder value and on the other, there is the social responsibility to curate the site by filtering out false and manipulative content that may undermine democracy and the wellbeing of its users. Notably, Zuckerberg originally dismissed the suggestion that Facebook had enabled a false news thereby facilitating interferences in democratic political processes.

We suggest that executives who persist in maintaining the outdated shareholder value myth (Stout, 2012) are engaging in a denial perhaps best described as a kind of existential "bad faith" (Sartre, 1993; Ashman, 2007). For too long, many business leaders have indulged in a similar kind of bad faith emblematic of their own denial that their companies have moral obligations for their impact (including unintentional) on society. Bad faith in the business leadership sense is a kind of rationalizing self-deception that spares one the trouble of making a courageous decision that challenges conventional wisdom (Ashman, 2007). It is something everyone engages in from time to time simply to get through the daily demands of social and organizational contexts, but overcoming it at defining moments is the mark of genuine ethical 
leadership (Badaracco, 1997). We suggest such considerations can be anchored by a unifying conceptualization of the core social impact—or purpose — the business fulfils. A recent survey of 3800 respondents conducted by the London Business School reports that fostering a responsible culture, demonstrating integrity and a commitment to long-term sustainability has become as crucial as maximizing shareholder returns (2013). This dual-purpose push is coming in part from ethical consumers who increasingly recognize that CSR from the sidelines is no longer enough (Harrison et al., 2005) and who reward responsible companies through brand loyalty, while punishing irresponsible ones (Bhattacharya \& Sen, 2004). Further pressure on organizations comes from the increasing evidence that links Anthropocene, specifically corporate actions, to the effects of climate change that is devastating for all humanity across the developed and the developing world (Hoffman \& Ehrenfeld, 2017). As a result, investors and business leaders are coming to grips with the realization that short-term profitability and long-term sustainability may be in conflict and that CSR and sustainability must thus move beyond an afterthought to an integration at the strategic level (Jain \& Jamali, 2017) toward what Battilana et al. refer to as the dual-purpose model (2017).

However, the search for win-win scenarios results in a myopic focus on primary stakeholders, constraining firms to get involved in solving broader societal problems (Barnett, 2019). Therefore, a single-minded focus on the economic strategies of business success inherently neglects the existential question of the purpose of the business organization, business education and the quality of our professional lives within it, that essentially calls for a holistic systems level change (Williams et al., 2017; Bansal, 2019). Business schools must hence refocus their efforts to train ethical leaders in honing the kind of social vision now required to overcome such bad faith and manage for long-term success. This will require reframing their conception of 
success beyond mere financial performance which is increasingly perceived as a liability since the global financial crisis of 2008 (Moules, 2015). We suggest this can be effectively accomplished by leveraging the motivational power of moral self-awareness.

\section{Moral Self-Awareness}

The social psychological literature has established a relationship between the self-importance of moral identity and moral thought and action (Aquino \& Reed II 2002; Reed II \& Aquino 2003). The wider literature on civic mindedness indicates that pride and shame are the most effective moral motivators of civic behavior (Bowles, 2016). To this end, there is evidence that ethical consumers are happier and have stronger repurchase intentions when motivated by their moral self-image than when motivated by more traditional moral emotions such as guilt and empathy (Hwang \& Kim, 2016). This indicates that individuals are more likely to engage in responsible economic behavior when focusing on how their actions reflect upon themselves than when focusing solely on the potential harm they may be alleviating.

Moral self-awareness (MSA) is a 4-stage evolving mindset informed by reflection on moral identity, namely what one's actions say about oneself given (a) the negative impact on others or society that one's action may effect, and (b) what one contributes to others and/or society by taking a given action (Friedland \& Cole, 2019). The MSA model builds on the moral identity literature established by Aquino by elaborating it into an evolving mindset. It also overlaps with the civic aspects of the Kohlbergian moral development literature but without that framework's reliance on contractarian and deontic theoretical constructs that Kohlberg himself suspected no more than 20 percent of the general population ever acknowledges (Kohlberg, 1984). As such, driven mainly by pride and potential shame avoidance, MSA suggests that 
painful emotional triggers of shame, guilt, and empathy become progressively less important at each successive stage of self-awareness, ultimately becoming unnecessary at the highest level of awareness. In this manner, the MSA approach relies on the more basic level of prosocial selfreflection that does not require adherence to abstract philosophical concepts, thus holding far greater potential to motivate a majority of actors. We discuss the four stages of the MSA framework below and how they may be leveraged system-theoretically.

\section{MSA Level 1 - Social Reflection}

At the first level, individuals rely chiefly upon negative feedback from observers in order to guilt or shame them into changing their behavior. Taking an example from the college classroom, even after being primed in a Tragedy of the Commons experiment to be self-interested, subjects gradually learned to temper their self-interest in subsequent rounds of decision-making after being shamed by other subjects left with fewer resources (Sadowski et al., 2013; 2015). Eventually, all subjects showed preference for lowered individual returns in favor of equitable and sustainable longer-term outcomes. This type of experiment demonstrates the power of negative feedback in inhibiting individual behavior that negatively impacts others.

\section{MSA Level 2 - Self-Reflection}

At the second level, individuals become more self-reflective. Rather than relying solely on outside observers to bring negative impacts on others to their attention, actors themselves start to take on the role as their own source of feedback. The mechanism by which this self-reflection occurs is observation of others' behavior or an extension of consideration beyond everyday stakeholders. Taking another example that might function in a classroom context, Cialdini et al. 
(1991) showed that subjects were 2.5 times less likely to litter in a room containing swept litter than in an unswept litter-strewn room. Observing the swept nature of the litter informs the observer that a clean room is desirable, thereby increasing the propensity of the observer to join in to help keep the room clean.

\section{MSA Level 3 - Anticipatory Self-Reflection}

At the third level, individuals start to become forward looking, conceiving of potential negative impacts on others before acting. This forward-looking behavior often comes after self-reflection on prior behavior has led to an internal sense of guilt or shame. For example, at a crucial turning point in Sadowski et al.'s classroom Tragedy of the Commons experiment (2013, p. 1335), one participant anxiously asked aloud, “Are we bad people?'” According to Sadowski et al., the point of the rhetorical question was not so much to shame or guilt the other group members as to attempt to reconcile the glaring inconsistency between one's prior action and one's selfperception. This "moral identity crisis" represents a crucial step in any individual's MSA development, and is akin to the existential crisis business education finds itself in at present.

\section{MSA Level 4 - Proactive Self-Reflection}

At the fourth, and highest, level, individuals become increasingly forward looking, considering not just their potential negative impacts on others, but their potential positive impacts and purposely engage in appropriate actions in order to realise those positive outcomes. At this highest level, individuals internalize the ideal of the self as potential hero rather than potential villain (Golpadas, 2014). By recognizing their place within a broader system and taking positive actions to improve that system, actors self-actualize by benefiting others beside themselves. At 
best, these decisions are conscientiously habit-forming, bringing persons closer to becoming whom they aspire to be (Aristotle, 2011) - a virtual ethical manifestation of the self within a broader system. This is the state of mind ethical consumers also tend to share as evidenced by Hwang and Kim (2016).

Table 1: Four Stages of Moral Self-Awareness

\begin{tabular}{|l|l|l|l|l|}
\hline & $\begin{array}{l}\text { Recognition } \\
\text { of } \\
\text { Externalities }\end{array}$ & \multicolumn{1}{|c|}{$\begin{array}{c}\text { Externality } \\
\text { Focus }\end{array}$} & \multicolumn{1}{|c|}{$\begin{array}{c}\text { System Theory } \\
\text { Focus }\end{array}$} & Motivators \\
\hline $\begin{array}{l}\text { Level 1 } \\
\text { Social reflection }\end{array}$ & Via others & Negative & Feedback & Guilt/ Shame \\
\hline $\begin{array}{l}\text { Level 2 } \\
\text { Self-reflection }\end{array}$ & $\begin{array}{l}\text { Via reflection } \\
\text { on outcomes } \\
\text { achieved by } \\
\text { others }\end{array}$ & Negative & Self-Feedback & $\begin{array}{l}\text { Guilt / Shame / } \\
\text { Pride }\end{array}$ \\
\hline $\begin{array}{l}\text { Level 3 } \\
\text { Anticipatory } \\
\text { Self-reflection }\end{array}$ & $\begin{array}{l}\text { Via forward- } \\
\text { looking } \\
\text { consideration }\end{array}$ & Negative & $\begin{array}{l}\text { Self-Feedback with } \\
\text { consideration of the } \\
\text { System }\end{array}$ & $\begin{array}{l}\text { Guilt / Shame / } \\
\text { Pride }\end{array}$ \\
\hline $\begin{array}{l}\text { Level 4 } \\
\text { Proactive } \\
\text { Self-reflection }\end{array}$ & $\begin{array}{l}\text { Via self- } \\
\text { actualization } \\
\text { of one's } \\
\text { internalized } \\
\text { values }\end{array}$ & Positive & $\begin{array}{l}\text { Consideration of } \\
\text { the System }\end{array}$ & Pride \\
\hline
\end{tabular}

Adapted from Friedland \& Cole, 2019; Friedland, 2019.

\section{System-Theoretic Dynamic}

A wide body of research has established that much of the motivational force of economic framing is determined by psychological factors such as envy (Gino \& Pierce, 2009), entitlement (Piff et al., 2011), and social class (Kraus et al., 2010; Piff et al., 2010). There is also considerable historical data suggesting that the shareholder value model propagated in business 
schools through the 1970's and 1990's is largely—though not entirely—responsible for the increasing prevalence of economic motivational framing in society at large (Stout, 2012). As a result, non-economic moral motivations have been gradually crowded-out of the wider culture to the point at which the logic and rhetoric of "incentivizing" has now become ubiquitous (Sandel, 2012; Bowles, 2016; Ghoshal, 2005). Fortunately, this also suggests that these are learned behaviors that can also be reversed, something that would be difficult if they were simply genetic predispositions. Indeed, Freeman's stakeholder theory (Freeman, 2010) and Stout's satisficing approach (Stout, 2012) have already had a significant impact on re-orienting the agenda in business schools. We contend that appeals to MSA can provide an effective means of shifting individuals away from instrumental economic framing toward more virtuously-motivated moral framing, given that such appeals have already been shown to be particularly effective in civic contexts such as jury duty, income tax payments, and nuclear waste disposal, where they tend to provide significantly greater motivational impetus than traditional financial incentives (Friedland \& Cole, 2017). We suggest that appeals to MSA can similarly enable business schools and firms to weave stakeholder and social responsibility into the strategic level, and not solely because of the business case for it.

This is because of the system-theoretical component of the model that is likely to come into play. Systems theory is an ecologically-inspired approach to describing the interrelated nature of complex systems, such as the different moving parts of a firm—manufacturing, R\&D, supply chain, finance, HRM, marketing, and so on —as parts of a unified system and not divorced from each other. As such, levers can be pulled by actors in certain parts that will have immediate or delayed effects in other parts of the system which will in turn create feedback to inform subsequent decision-making (Roberts, 1978). This approach has been used to describe 
myriad organizational logics including the dynamics of whistle-blowing decisions (Andrade, 2015) and structuring HRM practices for implementing sustainability strategies (Buller \& McAvoy, 2016). Such a systems approach worked for Amazon that was once heavily criticized for its wasteful and over-packaging practices. After facing years of social media backlash and complaints from ethically-engaged consumers, Amazon developed a series of new packing strategies aimed at reducing its carbon footprint. What followed was reduction in the size of its shipments, shipping of products in their original packaging, and combined shipments of multiple orders. This resulted in improvement in its shipping algorithms, optimization of transportation network, and efficiency in storage and distribution that ultimately saved Amazon millions of dollars (Green, 2017). We suggest that, even among organizations that are primarily shareholder focused, implementing MSA can gradually result in new mindsets being crowded-in across the entire system.

Business schools are also organized through multiple interdependent parts—admissions, instruction, research, fundraising, marketing and so on - that interact organically according to a shared societal mission. We argue that given the systems underpinning of MSA, business schools provide an ideal context for crowding-in an institutional culture of MSA. For example, by targeting students and hiring faculty already interested in social responsibility, business schools can further strengthen their positions while attracting new funding opportunities. Furthermore, as curricula move increasingly online, digital platforms can provide new tools for users to track their own behavior and compare it to their idealized versions of themselves, thereby reinforcing virtuous habits. Examples include screen time productivity, socially-responsible purchasing, and carbon emissions tracking (Friedland, 2019). What's more, as social beings, we tend to adopt the behavior of our peers, as has been shown with respect to socially-responsible purchasing 
including solar panels and electric vehicles (Frank, 2020). Thus, such formative social environments as academic cohorts have the capacity to spread positive behaviors contagiously.

\section{Part 1: Reframing the Purpose of Business}

The purpose-of-business debate has effectively been one between shareholder centric versus the stakeholder view of business. Shareholder primacy scholars suggest that "maximizing shareholder value is pro-stakeholder", while the stakeholder theorists contend that "creating value for stakeholders is decidedly pro-shareholder" (Freeman, 2010, p:366). Whether it is the proponents of shareholder value (Sundaram \& Inkpen, 2004; Friedman, 1970) or the supporters of the stakeholder view of the firm (Freeman, 2010; Stout, 2012), both sides agree that "governing a corporation requires purposeful activity". The core question that lies at the heart of the debate is to understand what is that purpose for which businesses exist. The recent global financial crisis and the exposure of corporate greed has only added fuel to the debate on the purpose of business, calling for new ideas and ways to make capitalism more responsible (Freeman, 2017).

In so doing, the academic community has issued rising calls to re-discover that purpose. For instance, the editors of the Academy of Management Journal (AMJ) have begun to encourage both academics and executives to re-define organizations as purposeful and explore how such organizations can transform society (Hollensbe et al., 2014). Following their lead, the overarching themes recent Academy of Management meetings such as "Opening Governance", "Making Organizations Meaningful", "At the Interface", "Improving Lives", and "Understanding the Inclusive Organization" from 2015 to 2019, respectively, signal a slow but sustained movement in this direction. The editors of AMJ are beginning to encourage both 
academics and executives to re-define organizations as purposeful and explore how such organizations can transform society (Hollensbe et al., 2014). Such framings emphasize that "organizations are a part, and not apart from society". (ibid, p. 1229). The editors further state:

In a world of sharply rising inequality, and still too often driven by seemingly insatiable desires for more, we urgently need to reframe how we collectively understand the purpose of business - the reason for which it is created and exists - and as citizens, consumers, and colleagues decide what we want and act accordingly. We need to allow our best values to be brought to work and ensure those values can be aligned with business purpose. There is nothing pre-determined about how the role of business in society will evolve in coming years and decades; it involves moral and social choice (ibid, p. 1233).

To unpack the purpose of an activity, a distinction must be drawn between why someone engages in it, i.e., motives and what it is for i.e., purpose (Duska, 1997). While the purpose of an activity is to normatively justify its existence by providing a legitimate reason for doing it, the motive for engaging in an activity is to accord it a psychological explanation. When applied to business, the question becomes "why someone engages in business" and "what is a business for"? Business is described as a societal practice that is instituted to provide goods and services in an efficient fashion (Duska, 1997). There are two key aspects here. First, business has to provide or promote some form of good or service to enhance societal wellbeing and second, business activity should be efficient and should result in profits. To address the first part, no well-ordered society could reasonably sanction the creation of a social institution that is strictly harmful to society with no tangible benefit. It thus follows that the purpose of the business - being a social institution —is to promote some form of wellbeing for society or part thereof. Second, the manner of provision of this wellbeing is such that it incentivizes the providers of capital and skills (i.e., investors, 
entrepreneurs, and others). Therefore, while profit is a necessary condition and a means for existence of business, it is not an end in itself (Collins \& Porras, 1994). For as Aristotle pointed out long ago, profits are merely the motive — and plausibly not the only one — for investors and entrepreneurs to engage in a business practice, but not the actual end or function of the human activity as a whole (Collins, 1987).

The business world has long celebrated and promoted the fastest growing companies as ideals to strive for. A proliferation of rankings is a testimony of this trend. Businesses increasingly aspire to be on Fortune's 500 and Forbes 500 lists that rank companies on the basis of their size, revenue, market cap, and profits. According to the Fortune president Alan Murray, "They're [these companies] now twice the size in terms of revenues of the next company on the list. They're really a behemoth. Now, they're not No. 1 in profits, they're not No. 1 in market value, but in terms of revenue's sheer size, they are No. 1" (CBS News, 2017). Inc.'s 20185000 lists the fastest growing companies in America as the most inspiring ones (INC. 5000, 2018). This constant expectation from our economic systems to grow indefinitely not only goes against the constraints of the biophysical environment (Kallis, 2017), but also pressures existing as well as aspiring corporate executives to play the numbers game while engaging in increasingly irresponsible behaviors. Therefore, while the purpose of the business is to produce goods and services in an efficient manner, efficiency often gets conflated with scaling ever upwards. In this Encyclical Letter (2015), Pope Francis writes:

"It's easy to accept the idea of infinite or unlimited growth, which proves so attractive to economists, financiers and experts in technology. It is based on the lie that there is an infinite supply of the earth's goods, and this leads to the planet being squeezed dry beyond every limit". 
Thus, the drive toward infinite global growth often comes at great social costs including reckless behaviors, environmental degradation as lengthening supply chains increase energy demands, as well as consumer dissatisfaction and employee alienation since the larger a business becomes, the more impersonal and locally disengaged it tends to get. The more businesses scale up, the more they are in a position to marshal governments via eminent domain to force out smaller independent enterprises and ultimately control entire neighborhoods, towns, and digital infrastructure, thereby undermining local autonomy (Moss, 2017) as well as personal privacy (Sadowski \& Pasquale, 2015). Indeed, these patterns are now becoming so evident as to cause widespread concern that the global push toward freer markets and perpetual growth may not maximize human flourishing and social welfare externalities (Pirson \& Lawrence, 2010; Friedland \& Cole, 2017). After all, production from local resources for local needs is logically the most sustainable way of conducting business.

As an institution, business schools have an important part to play in reframing the purpose of business by reframing the purpose of business education. Engaging MSA can make a significant difference by guiding business schools to reflect existentially on the purpose and efficacy of business organizations, which must include enhancing human wellbeing in tangible ways. Business schools can embed their curricula in this broader perspective by promulgating an awareness that whichever aims their students adopt will also reflect on the schools themselves, thereby defining those brands - positively or negatively—into the future. Such realization is emblematic of level four MSA for it turns ethical responsibility into a matter of moral identity. An example of this are the Better World MBA rankings that rates business schools on the basis of how they advance environmental and social goals (Murray, 2017) and the new Times Higher 
Education rankings that assess an institution's commitment towards Sustainable Development Goals (THE, 2019). By couching ethics and social responsibility in this existential light, farsighted schools will stand out by doing a better job of honing the moral attention of their students. We offer practical strategies for accomplishing this in part 3. But first we must also reframe the meaning of professional success.

\section{Part 2: Reframing the Meaning of Professional Success}

The standard conception of professional success that business schools tend to propagate by default is that of prodigious financial gains derived increasingly by some revolutionary market disruption. And while certain disruptions such as those of the sharing economy may implicitly be associated with a degree of social responsibility given their emphasis on localism and community, this can often be misleading (Horne, 2017). Indeed, swashbuckling founders of many of the most disruptive firms have maintained a callous disregard of the negative externalities they create. Facebook founder and CEO Mark Zuckerberg for example proudly adopted the slogan "move fast and break things" as a guiding ethos for the workplace.

Ultimately, this attitude emboldened him and his COO Sheryl Sandberg to discard social impact to the extent of providing a vast social media platform for a hostile foreign government to orchestrate a mass disinformation campaign against the American populace that ultimately imperiled the U.S. 2016 presidential election (Ellik et al., 2018). Similarly, Uber founder and CEO Travis Kalanick was criticized at numerous occasions, perhaps most notably for harboring a workplace rife with sexual harassment and making callous remarks on the precarious plight of his own drivers as his company depressed the salaries of taxi drivers across the nation (Levin, 2017). Some have linked such behavior to a self-serving moral relativism propagated in elite 
MBA programs (McDonald, 2018; 2017). Unfortunately, the business culture of brutal and brazen self-interest that continues to fuel such high-profile scandals as these will persist until leading business schools decide to make a clear break from promulgating the standard misconception of professional success as profit, power, and celebrity (Giacalone \& Promislo, 2019). Instead, business schools should explore re-defining success in terms of the degree of intellectual challenge balanced with the intellectual support they provide, alumni life satisfaction post-graduation, and tracking alumni career choices in more responsible organizations such as BCorps.

Similarly, Nash and Stevenson have pointed to an alternative conception of success in their book Just Enough (2005), based on findings gathered over their entire academic careers studying all kinds of differently successful people, and recently popularized in the Wall Street Journal bestseller Barking Up the Wrong Tree (Barker, 2017). Nash and Stevenson conducted a study comprising over 60 interviews and 300 hours with successful professionals and a survey of 90 executives attending Harvard Business School. What they ultimately discovered was that enduring success is almost never the result of a single-minded pursuit of profit, power, and status, but is instead aimed at four general outcomes:

1. Growth toward the extraordinary in some form: Innovation, personal stretch, expanded capacity beyond that of competitors, an ideal of excellence.

2. Personal fulfilment: Fulfilling some aspect of what one regards as necessary and meaningful to a good life.

3. Social significance: Contributing something valuable to society and the people one cares about.

4. Sustained impact beyond present effects: Not a flash in the pan but an impact that carries on in the lives of others $(2005$, p. 66). 
What is most striking about these elements of what might well be called a good life, in the Aristotelian sense of self-actualization, is that they do not refer to happiness in the usual hedonistic and quantifiable utilitarian sense. They have much more to do with deriving personal satisfaction from the activity of contributing directly to the greater good through an ethic and aesthetic of excellence. And while this is not necessarily a novel paradigm, business schools have generally been hard-pressed to crowd in this mindset within their graduates (Friedland, 2012). There are numerous systemic reasons for this failure as we have discussed, and what has been missing is the means to effectively inculcate it into business school culture. For it is one thing to tell someone what the good is and it is quite another to inspire them to actually go forth and do it. Moral identity provides a key motivating lynchpin to make this happen, for each one of us wants to be able to think of him- or herself as a basically good person. Self-image has consistently been shown to be morally motivating (Aquino \& Reed II, 2002), playing a key role in stimulating prosocial behavioral development (Friedland \& Cole, 2017) and subjects will only cheat to the extent that they can still maintain a belief in themselves as non-cheaters (Mazar et al., 2008). This is why appeals to civic pride have been and continue to be one of the most effective means of inspiring prosocial behavior (Gerber et al., 2008; Kunreuther \& Easterling, 1996; Schwartz \& Orleans, 1967).

At the same time, all individuals seek to fulfill their own desires and so it is perfectly acceptable for this to be their primary aim in life. But we should be cautious in framing a high image of someone who pursues nothing but his or her own self-interest. Indeed, the kind of person who always behaves this way - only ever doing good deeds cynically as a means for increased profit, power, and social status — cannot be regarded as a basically good person. For when taken to the extreme, this is akin to sociopathy, which incidentally has been estimated to be 
2-3 times more prevalent among corporate professionals than across the wider population (Boddy, 2011). When we discover that someone we know is really out for nothing more than personal gain, we quite naturally and understandably recoil. This is because what we expect of any basically good person is the common virtue of enlightened self-interest, namely, taking the greater good into account for its own sake, with the reasonable expectation that it will also benefit one indirectly in the long run. And this is the same standard to which consumers - and employees - increasingly hold the companies they interact with (Cone, 2016; Mintel, 2015). We all want to engage with the kinds of enterprises that make us feel part of something greater than ourselves, and that shared compact is essentially what every lasting ethical reputation is made of. Business schools can both harness and amplify the motivational power of MSA by systematically emphasizing in their promotional and course content that their students will only be able to continue seeing themselves as genuinely good persons by actively imbuing an ethically-integrated ideal of success in their professional lives after graduation. To accomplish this, school promotional events and literature must begin shifting away from reifying the conventional role models of industry movers and shakers to the kinds of business leaders - and ultimately their own alumni-who have thrived by staying true to a more integrated conception of professional success, thereby emulating third and fourth level MSA. They should invite such leaders to speak on how, where, and when they were best able to maintain and implement their vision, with an eye toward embedding those insights into the core college curriculum so as to guide students from the first and second levels of MSA to the third and fourth. Incidentally, many of these individuals will no doubt be women as they tend to seek greater balance between their personal and professional lives than do men (Parker \& Chusmir, 1991; Hakim, 2005). In this way, business schools will also promote inclusivity and gender equality by emphasizing 
female role models. But above all, crowding-in a culture of MSA will require business schools to reframe the very ethos of business education.

\section{Part 3: Reframing the Ethos of Business Education}

Mounting economic pressures from rising tuition costs, dwindling supplies of state funds and an increasingly consumer-oriented culture have created an instrumental mindset in many if not most incoming college students, impacting the very ethos of education in the twenty first century. As a result, business has now displaced the liberal arts as the most popular major in the U.S., claiming 1 out of every 5 bachelor's degrees granted (NCES, 2018). Rather than educating students to become more intellectually complex and critical, colleges generally and business schools in particular are placing their students on increasingly narrow vocational trajectories. What's more, many if not most students are woefully lacking in ethics education and critical thinking by the time they enter college (Giacalone \& Promislo, 2013). Therefore, it may well be that effecting the broader societal change we are advocating will not be possible without other educational reforms at the primary and secondary school levels.

Just as the distinction between motive and purpose is salient with respect to redefining business and professional success, so it is with respect to business education. Securing a highpaying executive job is often confused as the purpose of a business education. While the narrow and default guiding motive behind seeking a business education may be to attain financial success, the functional purpose of that education is in fact the dissemination of knowledge and development of critical insight, problem solving faculties, leadership skills, and vision required for setting and reaching a broad set of organizational and social goals. The way to reorient business education around such goals is by anchoring MSA into new and existing business 
modules as well as in the overall promotion of business schools themselves. New pedagogical research suggests that a distributed ethical training program that teaches students in multiple courses across the curriculum how to employ ethical reasoning skills via extracurricular and cocurricular activities, is significantly related to improvements in ethical decision making among graduating seniors (Parks-Leduc et al., 2020). This research further suggests that personality traits of conscientiousness and universalistic moral values are positively related to such behavior, while power values are negatively related. Building on this research, MSA stages can be leveraged to help change the mindset of those that demonstrate high power values and do not respond well enough to ethics trainings currently.

Furthermore, instilling an MSA mindset could strengthen ethical decision making by anchoring itself into each sub-discipline of management education. For example, within the discipline of finance, the shareholder primacy and shareholder wealth maximization paradigms have been dominant and have influenced legal and corporate governance statutes around the world, especially in the US., giving more power to shareholders in the corporate board room and making managers more sensitive to share prices. This academic shift was largely instigated by business school curricula, displacing the earlier managerialist and consumer-centric paradigms (Stout, 2012; Pirson \& Lawrence, 2010). Hence, this shift may also be reversed by employing the same means. In college modules introducing stakeholder constructs, the MSA approach could be effectively utilized. Level one of MSA relating to social reflection could be invoked to critically evaluate the wealth maximization paradigm. This could include arguments that underpin the unfair manner in which the economy is organized and the gross inequalities that result when wealth is concentrated in the hands of a few. This can be supported by data showing that by 2018 , the 26 wealthiest individuals own as many assets as 3.8 billion people on the 
planet, and that in the decade following the 2007 global financial crisis, the number of billionaires has nearly doubled, with the poorest $10 \%$ of Britons paying a higher effective tax rate than the richest $10 \%$, and $1 \%$ of Amazon owner Jeff Bezos' fortune exceeds the entire health budget of Ethiopia. Case studies on Uber and Ryanair can be used to demonstrate how neglecting social purpose can expose a company to considerable risks and long-term reputational and market share losses (Friedland, 2018). Through social reflection, students can come to realize that wealth accumulation creates negative externalities for society, resulting in feelings of shame associated with the idea of hoarding wealth at great cost to others' wellbeing.

Similarly, progressing to level two MSA—self-reflection—can be induced by observing the responsible actions of others in the domain of marketing. The Nike case is a good example here that shows how the company moved from level one to level two MSA after facing criticisms from consumers, activists and media over its involvement with sweatshops and unethical manufacturing in its supply chain (Zadek, 2007). Here, one can detail how Nike was put under intensive pressure by sustained aggressive special interest group campaigns that focused on the negative outcomes of Nike's business practices in the developing world. As a result, Nike eventually gave up its initial defensive stand on the issue and adopted an ethical code to avoid negative supply chain behaviors. Many other MNCs including Walmart and McDonald's have made similar changes, sometimes even exemplifying level three MSA by marshalling their massive monopsonic power to compel more responsible sourcing and lower carbon footprint across their entire supply chains (Economist, 2019). Such policies exemplify a commitment to avoiding potential future systemic harms to the global environment by internalizing externalities.

Ultimately at level four MSA, the transformation occurs at the strategic level, where individuals begin to seek to maximize the positive impacts of their actions on the world. The 
case of Patagonia, for example, helps think through this proactive level of self-awareness. The company's underlying business philosophy of "causing no unnecessary harm" (MSA 3) and "restoring the stability, integrity, and beauty of the web of life" (MSA 4) is reflected in their campaigns that discourage consumers from engaging in unnecessarily wasteful consumption through their worn-wear campaign (Patagonia, 2019). Patagonia displays easy-to-follow repair guides on their website that assists consumers in prolonging the use of products purchased from Patagonia. They have also identified partners through which consumers can exchange products, as well as offer ways to recycle products that are beyond repair or exchange. In this manner, Patagonia represents level four MSA through its commitment to go beyond harm avoidance to actually improving the lived environment by reducing unnecessary waste-generating material production. Similarly, level four MSA can also be applied in teaching innovative social-media marketing strategies that dramatically reduce the costs of traditional advertising-thereby freeing up revenue to cover the greater costs of responsible sourcing — as the trend-setting French shoe company Veja demonstrates (Segran, 2018).

Business schools should also consider how they might begin to redesign their curricula with an eye toward helping students progress along the path of increasing MSA. Some top programs have already introduced mandatory philosophy, ethics, and/or critical thinking coursework as early as the first year. Such modules can provide a refreshing opportunity for students to reflect on, re-examine and refine their own values. This may require additional tenure-track lines in ethics, CSR and philosophy and/or partnering with existing university faculty housed outside business. Still, even without stand-alone courses, ethics case-study exercises and common resource experiments simulating the tragedy of the commons (Sadowski et al., 2013) as previously mentioned, have been shown to be highly effective in crowding in a 
culture of MSA. MSA thinking could be tested in further related research exploring the extent to which self-awareness framing language is used to identify or articulate moral rationales, including the extent of their relevance to local versus global issues.

Simultaneously, business school promotion could be anchored in level four MSA, which can be accomplished in three specific ways:

1. By targeting and recruiting students already motivated by social purpose, as those students are the ones instigating this cultural shift. This can be accomplished via promotional materials and recruitment presentations and discussions.

2. By using civic and prosocial appeals to MSA, instead of crowding out those motivations in an atmosphere dominated by financial incentives. This can be anchored via stakeholder-theoretic modules in introductory coursework and core stand-alone courses in business ethics and CSR.

3. By re-envisioning their curricula as gateways to deeply rewarding careers, instead of mere pathways to profit, power, and social status. This can be accomplished via modules on health and wellbeing in organizational behavior as well as via inviting ethical leaders to give public talks.

This is not to say that business education should be re-conceived as a form of social service training or that there is no place therein for financial incentives. Only that such incentives should not be framed as end-goals in themselves but merely as economic means to achieving greater fulfilment. For while research has shown that financial incentives can crowd out moral motives in West Point cadets (Wrzesniewski et al., 2014), it turns out that they can also be used to 
buttress those same motives if framed as such, both within and beyond educational contexts. Students for example have been shown to succeed at higher rates when given economic incentives for high performance without crowding out moral motives so long as those incentives are framed as purely symbolic rewards for achieving something otherwise far more important. This framing is accomplished so long as the amount of the financial reward remains of relatively insignificant material value, say $\$ 100-\$ 500$ for passing a competitive essay or project competition in ethics and social responsibility (Sandel, 2012). Similar awards for faculty excellence in teaching, research, and service in in such areas can also be effective. The reward in such cases acts as a priding trigger of positive MSA. Similarly, economic disincentives such as fines can also buttress moral motives so long as they are clearly framed as negative moral signals, thus acting as subtle shaming triggers of negative MSA. This is why nominal plastic bag fees in Irish grocery stores and voting fines in Belgium and Australia, for example, have worked so effectively. It is not so much their cost as their symbolic normative significance that acts as a deterrent, such that economic disincentives for not showing up to vote or having to purchase disposable grocery bags act as a moral shaming trigger for shirking one's civic duty (Bowles, 2016). College campuses can implement similar strategies in order to encourage students and faculty to engage in greater environmental and civic responsibility. The right moral framing can effectively prevent punitive fines from collapsing into innocuous fees by couching them within clearly-articulated moral messaging. Unfortunately, absent such messaging, fines often will morph into fees, thereby crowding out moral motives and replacing them with economic ones.

To keep these trends from continuing on a wider cultural scale, business schools need to start re-framing the promise of future financial reward as merely the means to achieving far greater personal and social ends instead of as the ultimate aim in itself, which can be corrosive to 
virtuous character. As the MSA research suggests, persons on lower levels can advance to higher ones given the apt organizational contexts. Business schools can start orchestrating this process by highlighting alumni who have had successful and deeply satisfying careers in the social contribution sense without necessarily being celebrity movers and shakers or achieving great wealth.

\section{Conclusion}

The great influence business schools now enjoy both within universities and the wider culture has shifted the societal burden of educational leadership squarely onto their shoulders.

Ultimately, they can only live up to this responsibility by repositioning themselves with social contribution firmly placed at the center of their missions. This can be accomplished by crowding in a culture of moral self-awareness centered on reframing the purpose of business, reframing the meaning of professional success, and reframing the ethos of business education itself. Of course, students in business — or any other fields for that matter — aren't likely to one day all become virtuously-motivated change agents. While most are decidedly not, given the current cultural climate, many may still be re-oriented to a significant extent using the comprehensive approach we advance. Lawrence Kohlberg soberingly observed that only 20 percent of the general population during his time managed to reach the higher stages of moral development (Kohlberg, 1981). If this remains an accurate assessment, it leaves us much room for improvement. Broadbased cultural shifts can and do happen, and moral progress is a well-established historical phenomenon even with respect to business (Friedland \& Cole, 2017). While there are no magic bullets here, business schools have considerable power to push this evolving conversation forward. Leveraging the motivational power of moral self-awareness may help them to more 
effectively achieve this aim. In so doing, they will not only help secure their own futures in an increasingly uncertain landscape but may finally lead us out of the tunnel of economic necessity into daylight.

\section{References}

The Economist. (2019). A 25 -year battle to improve the image of McDonald's. Retrieved from https://www.economist.com/business/2019/02/07/a-25-year-battle-to-improve-the-imageof-mcdonalds.

Aquino, K. \& Reed II, A. (2002). The self-importance of moral identity. Journal of Personality and Social Psychology, 83, 1423-1440.

Andrade, J. (2015). Reconceptualizing whistleblowing in a complex world. Journal of Business Ethics, 128(2), 321-335.

Aristotle. (2011). Aristotle's Nicomachean Ethics, University of Chicago Press, Chicago, IL.

Ashman, I. (2007). Existentialism and Leadership: A Response to John Lawler with Some Further Thoughts, Leadership, 3(1), 91-106.

AthensCEO. (2018). American Financial Benefits Center: Major Companies Skipping Degree Requirements for Some Jobs. Retrieved from http://athensceo.com/news/2018/09/american-financial-benefits-center-major-companiesskipping-degree-requirements-some-jobs/.

Atiq, E. H. (2014). Why motives matter: Reframing the crowding out effect of legal incentives. Yale Law Journal, 123, 862-1117.

Badaracco, J. L. Jr. (1997). Defining Moments: When Managers Must Choose between Right and Right, Harvard Business Press.

Bansal, T. (2019). Why I no longer believe in the stakeholder perspective. Retrieved from https://www.nbs.net/articles/why-i-no-longer-believe-in-the-stakeholder-perspective

Barker, E. (2017). Barking Up the Wrong Tree: The Surprising Science Behind Why Everything You Know About Success Is (Mostly) Wrong, HarperCollins, New York. 
Barnett, M. L. (2019). The Business Case for Corporate Social Responsibility: A Critique and an Indirect Path Forward. Business \& Society, 58(1), 167-190.

Battilana, J., Pache, A., Sengul, M., \& Kimsey, M. (2017). The Dual-Purpose Playbook, Harvard Business Review, 97, 124-133.

Bhattacharya, C. B., \& Sen, S. (2004). Doing better at doing good: When, why, and how consumers respond to corporate social initiatives. California Management Review, 47(1), 9-24.

Bowles, S. (2016). The Moral Economy: Why Good Incentives are No Substitute for Good Citizens. Yale.

Buller, P. F., \& McEvoy, G. M. (2016). A Model for Implementing a Sustainability Strategy through HRM Practices. Business and Society Review, 121(4), 465-495.

Burchell, J., Kennedy, S., \& Murray, A. (2015). Responsible management education in UK business schools: Critically examining the role of the United Nations Principles for Responsible Management Education as a driver for change. Management Learning, 46, 479-497.

Businessweek. (2018). Best B-Schools. Retrieved from https://www.bloomberg.com/business-schools/2018/.

Byrne, J. (2019). It's Official: The MBA Degree is in Crisis. Forbes. Retrieved from https://www.forbes.com/sites/poetsandquants/2019/08/20/its-official-the-mba-degree-isin-crisis

Byrne, J. A. (2010). Meet the enemy of the MBA. Fortune. Retrieved from https://fortune.com/2010/11/16/meet-the-enemy-of-the-mba/.

Byrne, J. A. (2011). B-school rankings outrank academic quality for job recruiters. Fortune. Retrieved from http://fortune.com/2011/05/12/b-school-rankings-outrank-academic-quality-for-jobrecruiters/.

Caplan, B. (2018). The Case Against Education: Why the Education System is a Waste of Time and Money. Princeton.

CBS News. 2017. Fortune reveals America's top 500 companies Retrieved from https://www.cbsnews.com/news/fortune-500-revealed-2017-list-revenue-largestcorporations/.

Chandler, D. (2017). Strategic Corporate Social Responsibility, Sage. Washington D.C. 
Christensen, L. J., Peirce, E., Hartman, L. P., Hoffman, W. M., \& Carrier, J. (2007). Ethics, CSR, and sustainability education in the Financial Times top 50 global business schools: Baseline data and future research directions. Journal of Business Ethics, 73, 347-368.

Cialdini, R. B., Kallgren, C. A., \& Reno, R. R. (1991). A focus theory of normative conduct: A theoretical refinement and reevaluation of the role of norms in human behavior. Advances in Experimental Social Psychology, 24, 201-234.

Collins, J. C., \& Porras, J. I. (1994). Built to last. Successful Habits of Visionary Companies. New York.

Conley, B. (2019). The Great Enrollment Crash: Students aren’t showing up. And it's only going to get worse. Retrieved from https://www.chronicle.com/interactives/20190906-Conley.

Cone, (2016). Cone Communications Millennial Employee Engagement Study. Retrieved from http://www.conecomm.com/research-blog/2016-millennial-employee-engagementstudy\#download-the-research.

Dennis, G. (2017). Amazon fixed the most annoying thing about receiving online orders, Business Insider. Retrieved from https://www.businessinsider.com.au/amazon-fixes-packaging-to-be-more-efficient-201712.

Doherty, B., Meehan, J., \& Richards, A. (2015). The business case and barriers for responsible management education in business schools. Journal of Management Development, 34, 34-60.

Duska, R. F. (1997). The why's of business revisited. In From the Universities to the Marketplace: The Business Ethics Journey (pp. 191-199). Springer, Dordrecht.

Edelson, S. A. (2017). Promethian Business: From Financial Hedonism to Financial Eudaimonia. Journal of Management Inquiry. 28(4), 1-6.

Ellik, A. B., Westbrook, A. \& Kessel, J. M. (2018). Operation Infektion, New York Times, Retrieved from https://www.nytimes.com/2018/11/12/opinion/russia-meddling-disinformation-fakenews-elections.html

Feloni, R., \& Baer, D. (2014). The 25 Most Successful Harvard Business School Graduates. Retrieved from https://www.businessinsider.com/famous-harvard-business-school-alumni-2014-9?IR=T.

Fink, L. (2018). Larry Fink's letter to CEOs: A Sense of Purpose. Retrieved from https://www.blackrock.com/corporate/investor-relations/larry-fink-ceo-letter.

Frank, R. H. (2020). Under the Influence: Putting Peer Pressure to Work. Princeton. 
Freeman, R. E. (2017). The new story of business: Towards a more responsible capitalism. Business and Society Review, 122, 449-465.

Freeman, R. E. (2010). Strategic management: A stakeholder approach. Cambridge University Press.

Freeman, R. E., Wicks, A. C., \& Parmar, B. (2004). Stakeholder theory and "the corporate objective revisited". Organization Science, 15, 364-369.

Freeman, R. E., \& Ginena, K. (2015). Rethinking the purpose of the corporation: Challenges from stakeholder theory. Notizie di Politeia, 31(117), 9-18.

Friedland, J. (2019). Activating Moral Agency by Design: A Model for Ethical AI Development. MIT Sloan Management Review, 60(4), 2019.

Friedland, J. (2018). To Weather Reputational Storms, Get Caught Doing the Right Thing. Irish Times. Retrieved from https:/www.irishtimes.com/business/work/to-weather-reputational-storms-get-caughtdoing-the-right-thing-1.3351955.

Friedland, J. (2012). Beyond Empiricism: Realizing the Ethical Mission of Management. Business and Society Review, 117, 329-356.

Friedland, J. \& Cole, B. M. (2019). From Homo-Economicus to Homo-Virtus: A SystemTheoretic Model for Raising Moral Self-Awareness. Journal of Business Ethics, 155(1), 191-205.

Friedman, M. (1970). The Social Responsibility of Business Is to Increase Its Profits. Retrieved from https://www.nytimes.com/1970/09/13/archives/a-friedman-doctrine-the-socialresponsibility-of-business-is-to.html.

Fry, L. W. (2003). Toward a theory of spiritual leadership, The Leadership Quarterly, 14(6), 693-727.

Ghoshal, S. (2005). Bad management theories are destroying good management practices. Academy of Management Learning \& Education, 4(1), 75-91.

Giacalone, R. A. \& Promislo, M. D. (2019). The Menace of Misinformation: Faculty Misstatements in Management Education and Their Consequences. Journal of Management Education, DOI 1052562919826613.

Giacalone, R. A. \& Jurkiewicz, C. L. (2004). The interaction of materialist and postmaterialist values in predicting dimensions of personal and social identity, Human Relations, 57(11), 1379-1405. 
Giacalone, R. A. \& Promislo, M. D. (2006). Business Ethics and Social Responsibility Education: Shifting the Worldview, Academy of Management Learning \& Education, 5(3), 266-277.

Giacalone, R. A. \& Promislo, M. D. (2013). Broken When Entering: The Stigmatization of Goodness and Business Education, Academy of Management Learning \& Education, 12(1), 86-101.

Gino, F. and Pierce, L. (2009). The abundance effect: Unethical behavior in the presence of wealth. Organizational Behavior and Human Decision Processes, 109, 142-155.

Golpadas, A. (2014). Marketplace sentiments. Journal of Consumer Research, 41, 995-1014.

Gond, J.-P., Palazzo, G., \& Basu, K. (2009). Reconsidering Instrumental Corporate Social Responsibility through the Mafia Metaphor. Business Ethics Quarterly, 19, 57-85.

Gratton, L. (2013). Restoring faith in leadership. Retrieved from https://www.forbes.com/sites/lyndagratton/2013/05/02/restoring-faith-inleadership/\#4f04d5912381.

Greathouse, J. (2012). Business Tips From College Dropouts: Zuckerberg, Jobs, Gates, Dell, Ellison, Branson and Disney, Forbes. Retrieved from https://www.forbes.com/sites/johngreathouse/2012/06/05/business-tips-from-collegedropouts-zuckerberg-jobs-gates-dell-ellison-branson-and-disney/\#695cb735377a.

Guerrera, F. (2009). Welch condemns share price focus. Financial Times. Retrieved from https://www.ft.com/content/294ff1f2-0f27-11de-ba10-0000779fd2ac.

Harrison, R., Newholm, T., \& Shaw, D. (2005). The Ethical Consumer. Sage: London.

Hoffman, A. J. (2018). The next phase of business sustainability. Stanford Social Innovation Review, 16(2), 34-39.

Hoffman, A. J., \& Ehrenfeld, J. R. (2017). The fourth wave: Management science and practice in the age of the Anthropocene. In Corporate Stewardship, 228-246, Routledge.

Holger, D. \& Sardon, M. (2020). BlackRock joins world's largest investor group on climate change. Retrieved from https://www.wsj.com/articles/blackrock-joins-worlds-largest-investor-group-on-climatechange-11578594349

Hollensbe, E., Wookey, C., Hickey, L., George, G., \& Nichols, C. V. (2014). Organizations with purpose. Academy of Management Journal, 57(5), 1227-1234.

Horne, R. (2017). Sharing economy sounds caring, but let's put it to the ethical city test, The Conversation. Retrieved from 
https://theconversation.com/sharing-economy-sounds-caring-but-lets-put-it-to-the-ethicalcity-test-87165.

Hwang, K. \& Kim, H. (2016). Are Ethical Consumers Happy? Effects of Ethical Consumers' Motivations Based on Empathy Versus Self-orientation on Their Happiness. Journal of Business Ethics, 151, 579-598.

Jain, T. (2018). Cheap talk can cost when it comes to social responsibility. Irish Times. Retrieved from

https://www.irishtimes.com/business/work/cheap-talk-can-cost-when-it-comes-to-socialresponsibility-1.3400257.

Jain, T. (2017). Decoupling corporate social orientations: A cross-national analysis. Business \& Society, 56, 1033-1067.

Jamali, D., Jain, T., Samara, G, \& Zoghbi, E. (2018). Understanding CSR Behaviors across the Middle East: A Review and a Research Agenda. In Academy of Management Proceedings. Academy of Management, NY.

Kallis, G. (2017). Radical dematerialization and degrowth. Philosophical Transactions of the Royal Society A: Mathematical, Physical and Engineering Sciences, 375, 2095.

Karaian, D. (2016) Was it Worth it? The Economist. Retrieved from https://www.economist.com/whichmba/mba-diary-was-it-worth-it.

Keynes, J. M. (1963). Essays in Persuasion, New York: W. W. Norton \& Co.

Kraus, M. W., Cote, S. and Keltner, D. (2010). Social class, contextualism and empathic accuracy. Psychological Science, 21, 1716-1723.

Khurana, R. (2007). From Higher Aims to Hired Hands. Princeton.

Kohlberg, L. (1981). The Philosophy of Moral Development: Moral Stages and the Idea of Justice, Harper \& Row. New York.

Levin, S. (2017). Uber's scandals, blunders and PR disasters: the full list, The Guardian. Retrieved from https://www.theguardian.com/technology/2017/jun/18/uber-travis-kalanick-scandal-prdisaster-timeline.

London Business School. (2013). Rethinking the responsibility of business leaders. Retrieved from https://www.london.edu/faculty-and-research/lbsr/rethinking-the-responsibility-ofbusiness-leaders. 
MacLellan, L. (2019). Nearly 200 CEOs just agreed on an updated definition of "the purpose of a corporation". Retrieved from

https://qz.com/work/1690439/new-business-roundtable-statement-on-the-purpose-ofcompanies/

Margolis, J. D., Elfenbein, H. A., \& Walsh, J. P. (2009). Does it pay to be good... and does it matter? A meta-analysis of the relationship between corporate social and financial performance. SSRN Working paper. Available at https://papers.ssrn.com/sol3/papers.cfm?abstract id=1866371.

Matten, D., \& Moon, J. (2004). Corporate social responsibility. Journal of Business Ethics, 54, 323-337.

McDonald, D., (2017). The Golden Passport: Harvard Business School, the Limits of Capitalism, and the Moral Failure of the MBA Elite, Harper Business, New York.

McDonald, D. (2018). "When you get wealthy, you start to buy your own bullshit": The Miseducation of Sheryl Sandberg. Vanity Fair. Retrieved from https://www.vanityfair.com/news/2018/11/sheryl-sandberg-harvard-business-schoolleadership.

McWilliams, A., Siegel, D. S., \& Wright, P. M. (2006). Corporate social responsibility: Strategic implications. Journal of Management Studies, 43(1), 1-18.

Meet the Most Inspiring Companies of 2018 - Inc. 5000. (2018). Retrieved from https://www.inc.com/james-ledbetter/2018-inc5000-us-economic-growth-jobs.html.

Mintel. (2015). Retrieved from 56\% of Americans stop buying from brands they believe are unethical. http://www.mintel.com/press-centre/social-and-lifestyle/56-of-americans-stop-buyingfrom-brands-they-believe-are-unethical.

Moon, J., \& Orlitzky, M. (2011). Corporate social responsibility and sustainability education: A trans-Atlantic comparison. Journal of Management \& Organization, 17, 583-603.

Moules, J. (2015). Business schools adapt to changing times: Ethics and risk management take centre stage following financial crisis. Financial Times. Retrieved from https://www.ft.com/content/b6b5e4a6-0945-11e5-b643-00144feabdc0.

Moss, J. (2017). Vanishing New York: How a Great City Lost Its Soul. Harper Collins. New York.

Murray, S. (2017). The World's 15 Top Business Schools For Making A Social Impact. Business Because. Retrieved from https://www.businessbecause.com/news/mba-rankings/4853/top-15-schools-for-socialimpact. 
Nash, L \& Stevenson, H. (2005). Just Enough: Tools for Creating Success in Your Work and Life, Wiley. New York.

Natale, S. M. \& Doran, C. (2012). Marketization of Education: An Ethical Dilemma. Journal of Business Ethics, 105, 187-196.

Navarro, P. (2008). The MBA Core Curricula of Top-Ranked U.S. Business Schools: A Study in Failure? Academy of Management Learning \& Education, 7(1), 108-123.

National Center for Education Statistics (2018). The Condition of Education: National Degree Fields. Retrieved from https://nces.ed.gov/programs/coe/indicator cta.asp.

The Economist. (2016). Nothing special: MBAs are no longer prized by employers. Retrieved from https://www.economist.com/whichmba/nothing-special-mbas-are-no-longer-prizedemployers.

NUS. (2019). Sustainability in Education 2018. Retrieved from https://nusdigital.s3euwest1.amazonaws.com/document/documents/48400/2811e7b5e6d2 585bbf940a18d3810012/20190213 State of the sector report 2018 DRAFT.pdf.

Orlitzky, M., Schmidt, F. L., \& Rynes, S. L. (2003). Corporate social and financial performance: A meta-analysis. Organization Studies, 24, 403-441.

Ortmans, L. (2018). FT Global MBA ranking 2018: methodology and key. Retrieved from https://www.ft.com/content/1bf3c442-0064-11e8-9650-9c0ad2d7c5b5.

Parker, B. \& Chusmir, L. H. (1991). Motivation Needs and Their Relation to Life Success. Human Relations, 44(12), 1301-12.

Parks-Leduc, L, Milligan, L., Rutherford, M. A. (2020). Can Ethics Be Taught? Examining the Impact of Distributed Ethical Training and Individual Characteristics on Ethical Decision Making. Academy of Management Learning \& Education, published online 3/26: 2020. Retreived from https://doi.org/10.5465/amle.2018.0157

Parliament UK. (2018). Returns to a degree. Retrieved from https://researchbriefings.parliament.uk/ResearchBriefing/Summary/CBP-8389.

Patagonia's Mission Statement (n.d.). Retrieved from https://www.patagonia.com/company-info.html.

Piff, P. K., Kraus, M. W., Côté, S., Cheng, B. and Keltner, D. (2010). Having less, giving more: The influence of social class on prosocial behavior. Journal of Personality and Social Psychology, 99, 771-784. 
Piff, P. K., Stancato, D. M., Côté, S., Mendoza-Denton, R. and Keltner, D. (2011). Higher social class predicts unethical behavior. Proceedings of National Academy of Sciences, 109, 4086-4091.

Pirson, M. A. \& Lawrence, P. R. (2010). Humanism in Business-Toward a Paradigm Shift? Journal of Business Ethics, 93, 553-565.

Pfeffer, J. \& Fong, C. T. (2002). The End of Business Schools? Less Success Than Meets the Eye. Academy of Management Learning \& Education, 1(1), 78-95.

Pope Francis. (2014). Encyclical letter of the holy father francis on care for our common home. Retrieved from http://w2.vatican.va/content/francesco/en/encyclicals/documents/papafrancesco 20150524 enciclica-laudato-si.html.

Rasche, A., \& Escudero, M. (2009). Leading change-The role of the principles for responsible management education. zfwu Zeitschrift für Wirtschafts-und Unternehmensethik, 10(2), 244-250.

Reed, A., II, \& Aquino, K. F. (2003). Moral identity and the expanding circle of moral regard toward out-groups. Journal of Personality and Social Psychology, 84, 1270-1286.

Roberts, N. (1978). Teaching dynamic feedback systems thinking: An elementary view. Management Science, 24(8), 836-843.

Rothman, L. (2016). Putting the Rising Cost of College in Perspective, Time Magazine. Retrieved from http://time.com/4472261/college-cost-history/.

Sadowski, J., Seager, T. P., Selinger, E., Spierre, S. G. and Whyte, K. P. (2013). An experiential, game-theoretic pedagogy for sustainability ethics. Science and Engineering Ethics, 19, 1323-1339.

Sadowski, J. \& Pasquale, F. (2015). The Spectrum of Control: A Social Theory of the Smart City. First Monday, 20(7).

Sadowski, J., Seager, T. P., Selinger, E., Spierre, S. G. and Whyte, K. P. (2015). Intergroup cooperation in common pool resource dilemmas: The role of ethical leadership. Science and Engineering Ethics, 5, 1197-1219.

Sandel, M. J. (2012). What Money Can't Buy: The Moral Limits of Markets, Farrar, Straus and Giroux. New York.

Sartre, J. P. (1993). Being and Nothingness, Simon and Schuster. New York.

Scott, M. (2015). Sustainability now key selling point for business schools attracting students, The Guardian. Retrieved from 
https://www.theguardian.com/sustainable-business/2015/feb/09/are-business-schoolstaking-sustainability-seriously.

Seegran, E. (2018). Veja Wants to Make the Most Sustainable Sneaker in the World. Fast Company. Retrieved from https://www.fastcompany.com/40532184/veja-wants-to-make-the-most-sustainablesneaker-in-the-world.

Seetharaman, D, Alpert, L. I., \& Mullen, B. (2018). Facebook to Overhaul How It Presents News in Feed, Wall Street Journal. Retrieved from https://www.wsj.com/articles/facebook-considers-prioritizing-trustworthy-news-sourcesin-feed-1515714244.

Stout, L. A. (2012). The shareholder value myth: How putting shareholders first harms investors, corporations, and the public. Berrett-Koehler Publishers.

Sundaram, A. K., \& Inkpen, A. C. (2004). The corporate objective revisited. Organization Science, 15, 350-363.

Tang, Z., Hull, C. E., \& Rothenberg, S. (2012). How corporate social responsibility engagement strategy moderates the CSR-financial performance relationship. Journal of Management Studies, 49, 1274-1303.

THE, 2019. THE University Impact Rankings 2019: methodology. Times Higher Education. Retrieved from https://www.timeshighereducation.com/world-university-rankings/methodology-impactrankings-2019\#survey-answer.

Vranica, S. (2018). Unilever Threatens to Reduce Ad Spending on Tech Platforms That Don't Combat Divisive Content, Wall Street Journal. Retrieved from https://www.wsj.com/articles/unilever-threatens-to-reduce-ad-spending-on-techplatforms-that-dont-combat-divisive-content-1518398578.

Williams, A., Kennedy, S., Philipp, F., \& Whiteman, G. (2017). Systems thinking: A review of sustainability management research. Journal of Cleaner Production, 148, 866-881.

Wrzesniewski, A., Schwartz, B., Cong, X., Kane, M., Omar, A., \& Kolditz T. (2014). Multiple motives don't multiply motivation. Proceedings of the National Academy of Sciences, 111, 1990-1995.

Zadek, S. (2007). The Path to Corporate Responsibility. In Zimmerli W.C., Holzinger M., Richter K. (eds) Corporate Ethics and Corporate Governance (pp. 159-172). Springer, Berlin, Heidelberg. 